\title{
The Mediating Effect of Financial Distress on Audit Tenure and Auditor Switching Towards Audit Delay
}

\author{
Wiyarni*, Bunyamin \\ STIE Malangkucecwara Malang \\ Malang, Indonesia \\ *wiyarni08@gmail.com
}

\begin{abstract}
The aim of this study is to investigate the impact of audit tenure and auditor switching as an intervening variable on audit delay and financial distress. Manufacturing companies listed on the Indonesian Stock Exchange for the period 2016 to 2018 are the population of this analysis. This research uses purposeful sampling to obtain 14 businesses as an item. The hypothesis test is conducted using a partial least square. This study found that there is no effect of audit tenure and audit switching on audit delay. Audit tenure does not affect financial distress, but auditor switching affects financial distress. Indirectly, both audit tenure and auditor switching don't affect audit delay through financial distress.
\end{abstract}

Keywords-audit tenure, auditor switch, financial distress, audit delay

\section{INTRODUCTION}

The completion of the audit report of a corporation is a key factor in deciding the timeliness of the presentation of its annual report [1]. As for the users of the financial report, several parties have established that the timeliness of annual reports is an essential feature of financial accounting information [2]. If they provide correct and timely details, financial reports would be very useful. Timeliness ensures that financial reports should be open to consumers as soon as possible and that financial statements need to be useful as well.

Several researchers are examining the determinants of the timelines for earning announcements [3,4,56]. These determinants are profitability ratio, audit firm form, business size, and leverage [1]; company management, debt percentage, company size, and revenue sign [3]; company size, debt-equity ratio, profitability, multinational company branches, and audit company size [4]; while Jaggi and Tsui examine the audit delay [5].

This research seeks to see the other audit timeline determinants, specifically the audit latency. Audit tenure, auditor swapping, and financial distress are these determinants. Almutairi et al. [7] researched audit tenure, but focused on the relationship between information on audit tenure and asymmetry. Similar to Almutairi et al. [7], though not linked to audit pause, Al-Thuneibat et al. [8] researched audit tenure. The further the relationship between audit tenure and audit efficiency is concentrated on. Research has been performed on the relationship between audit tenure and audit delay [9]. They found that by hiring a specialist auditor, short audit tenure leading to a longer audit report lag can be minimized. Therefore, Dao and Pham included in their analysis the integrity of the auditor, who is a specialized auditor [9].

The relationship between trained opinions and auditor switching was studied by Chow and Rice [10] in relation to auditor switching. They noticed that after providing competent opinions, businesses often turn from the auditor. However, when competent opinion is obtained, there is no firm systemic move to audit firms. In addition, they have found that eligible companies that are already switching auditors then get cleaner opinions. The relationship between financial distress and the standard of financial reporting was analyzed by Haji-Abdullah and Wan-Hussin in relation to financial distress [11].

From the previous analysis above, it can be seen that the study seldom relates to audit tenure, auditor switching, and financial distress along with audit delay. This study therefore aims to explore the effects on audit delay of audit tenure, auditor switching, and financial distress. More precisely, financial distress is used as an interfering variable in this research.

\section{RESEARCH FRAMEWORK}

The research framework of this study can be seen in figure 1 below.

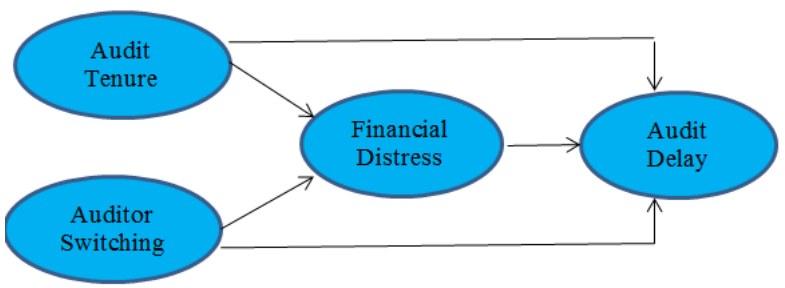

Fig. 1. Research framework. 


\section{A. Hypotheses}

Based on the research framework above, the hypotheses of this study are:

H1: Audit tenure has a significant impact on audit delay delay

$\mathrm{H} 2$ : Auditor switching has a significant impact on audit

H3: Auditor tenure has a significant impact on financial distress

H4: Auditor switching has a significant impact on financial distress

H5: Financial distress has a significant impact on audit delay

H6: Audit Tenure has a significant impact on audit delay with financial distress as an intervening variable

H7: Auditor switching has a significant impact on audit delay with financial distress as an intervening variable

\section{RESEARCH METHODOLOGY}

In order to investigate the impact of audit tenure and auditor switching on audit delay with financial distress as a variable interfering, this analysis used the partial least-square (PLS) model. The data used for this research is secondary data obtained from the Indonesia Stock Exchange's official website at www.IDX.co.id. Manufacturing businesses listed on the Indonesian Stock Exchange for the period 2016-2018 are the population of this study. To determine the sample, this study used purposive sampling with criteria:

- Food and beverage companies

- Companies have a complete annual report for the years $2016-2018$

- Companies have complete data related to the research variables.

Based on the purposive sampling, the sample of this study is 14 food and beverage companies and by using time series for 3 years, so that the sample is 42 .

This study has four variables. These variables are audit tenure, auditor switching, financial distress, and audit delay. Audit tenure is measured by counting the number of years spent by the auditor who works for the same client. The early year starts with "1" and will be added with another "1" if the following year the client has an engagement with the same public accounting firm [12]. Auditor switching is measured using a dummy variable. Companies who have been audited by different public accounting firms either voluntarily or mandatory will be given a "1" code. Meanwhile, the companies who have been audited by the same public accounting firm will be given a "0" code [12]. For financial distress, this study used debt to asset ratio (DAR) as a measurement. The formula is shown as follows:

$$
\text { DAR }=\frac{\text { Total Debts }}{\text { Total Assets }} \times 100 \%=\ldots \ldots
$$

For audit delay, it is measured by count from the closed book period or 31 December until the auditor reports their audited financial statement [12].

Data obtained was processed using SmartPLS 3.0 software to analyze the impact of audit tenure and auditor switching on audit delay with financial distress as an intermediate variable. The study consists of the outer model and the inner model (measurement model) (structural model). To ensure that the measurements used are accurate and consistent, examination of the outer model is carried out. The relationship between latent variables and their indicators or how each indicator is related to its latent variables is defined by the outer model analysis [13]. The study of the outer model consists of convergent validity, validity of discriminants and reliability. The inner model explains one variable's relationship to other variables. The internal model is tested by looking at the percentage of variance described by the $\mathrm{R} 2$ value, which is the model's goodness-fit measure [13].

Hypothesis testing is conducted through a bootstrapping mechanism to predict a causality relationship by obtaining the T-test parameter. Testing is declared influential or accepted in a research hypothesis if $\mathrm{t}$ count $>\mathrm{t}$ - table, while hypothesis testing is declared not to influence or is rejected if $\mathrm{t}$ count $<\mathrm{t}$ table. Via the P-values, with a significance level of 0.05 , the significance of the hypothesis test results can also be seen. The error can still be tolerated if the P-value is less than 0.05 . If the $\mathrm{P}$-value is greater than 0.05 , however, the error cannot be tolerated or always needs to be considered.

\section{RESULTS AND DISCUSSION}

\section{A. Measurement Model}

The results of the measurement model can be used to test the study hypothesis if the criteria of convergent validity, discriminant validity, and composite reliability have been met by all indicators in the PLS model. Convergent validity checks can be seen against the construct at the loading factor value of each indicator. The loading factor limit used for confirmatory research is 0.7 , while the loading factor limit used for exploratory research is 0.6 and the loading factor limit used for production research is 0.5 . Since this research is true, the loading factor limit used is 0.7 . The results of the loading factors of each indicator can be seen in figure 2 below. 


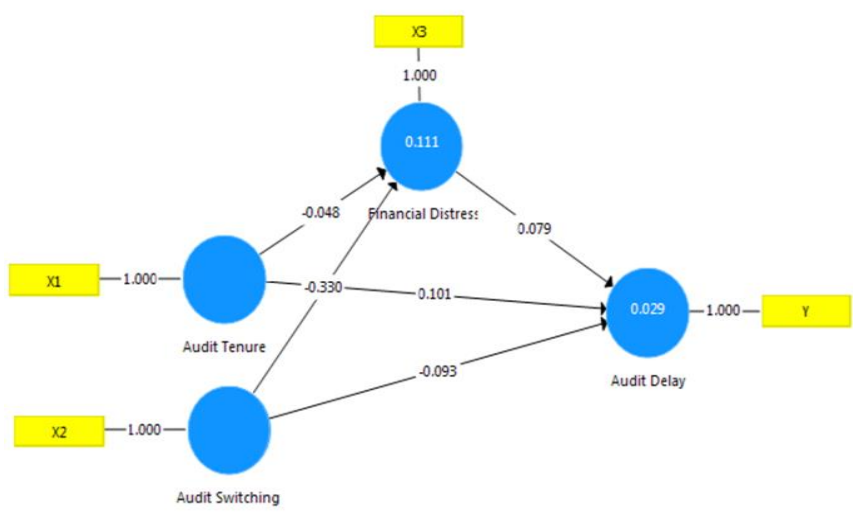

Fig. 2. Outer model.

Based on the estimation results of the PLS model in figure 2 , all indicators have a loading factor value of 1.000 (above 0.7) so that the model has met the convergent validity requirements. Apart from looking at the loading factor value of each indicator, the convergent validity can also be assessed from the AVE value of each construct. The PLS model is declared to have met the convergent validity of the AVE value of each construct is higher than 0.5. The AVE value of each construct can be seen in Table 1 below.

TABLE I. The Value of AVerage Variance Extracted

\begin{tabular}{|c|c|}
\hline & Average Variance Extracted (AVE) \\
\hline Audit Delay & 1.000 \\
\hline Auditor Switching & 1.000 \\
\hline Audit Tenure & 1.000 \\
\hline Financial Distress & 1.000 \\
\hline
\end{tabular}

Source: SmartPLS results

Based on the table above, it can be inferred that all variables meet the estimated value of the AVE criterion, which is greater than 0.50 . The results of this data analysis indicate that the highest value, namely 1,000, is for all variables. So, it can be inferred that truth is declared for all variables.

From the Cronbachs Alpha value and the Composite Reliability value of each construct, the reliability of the constructs can be evaluated. More than 0.7 is the recommended composite reliability and the alpha value of Cronbach.

TABLE II. COMPOSITE RELIABILITY

\begin{tabular}{|c|l|l|l|l|}
\hline & $\begin{array}{c}\text { Cronbach's } \\
\text { Alpha }\end{array}$ & rho_A & $\begin{array}{c}\text { Composite } \\
\text { Reliability }\end{array}$ & $\begin{array}{c}\text { Average } \\
\text { Variance } \\
\text { Extracted } \\
\text { (AVE) }\end{array}$ \\
\hline Audit Delay & 1.000 & 1.000 & 1.000 & 1.000 \\
\hline $\begin{array}{c}\text { Auditor } \\
\text { Switching }\end{array}$ & 1.000 & 1.000 & 1.000 & 1.000 \\
\hline $\begin{array}{c}\text { Audit } \\
\text { Tenure }\end{array}$ & 1.000 & 1.000 & 1.000 & 1.000 \\
\hline $\begin{array}{c}\text { Financial } \\
\text { Distress }\end{array}$ & 1.000 & 1.000 & 1.000 & 1.000 \\
\hline
\end{tabular}

Source: SmartPLS results
The results of the reliability test in the table above show that all constructs have a composite reliability value of 1,000 (> 0.7) and Cronbachs alpha $>0.7$, which shows that the reliability needed has been met by all constructs.

\section{B. Structural Model}

For testing the hypotheses, a structural model or inner model is used. The direct effect significance evaluation, indirect effect testing and calculation of the impact of each exogenous variable on the endogenous variable was included in the internal model testing. To test the study hypothesis, both of these experiments will be included. As the study hypothesis is a one-way hypothesis, if the $\mathrm{P}$-value $<0.05$ and $\mathrm{t}$ count $>1.68$, the exogenous variables have a major impact on endogenous variables.

The direction of the relationship between the effect of exogenous and endogenous variables can be seen based on the outcomes of the significance test. From the value of the original sample of each impact association, the path of the relationship can be seen. If the direction is positive, then the endogenous effect of exogenous variables is positive, while the relationship direction is opposite if the original sample value is negative. The results of the model estimation for testing the hypothesis in this study can be shown in figure 3 below.

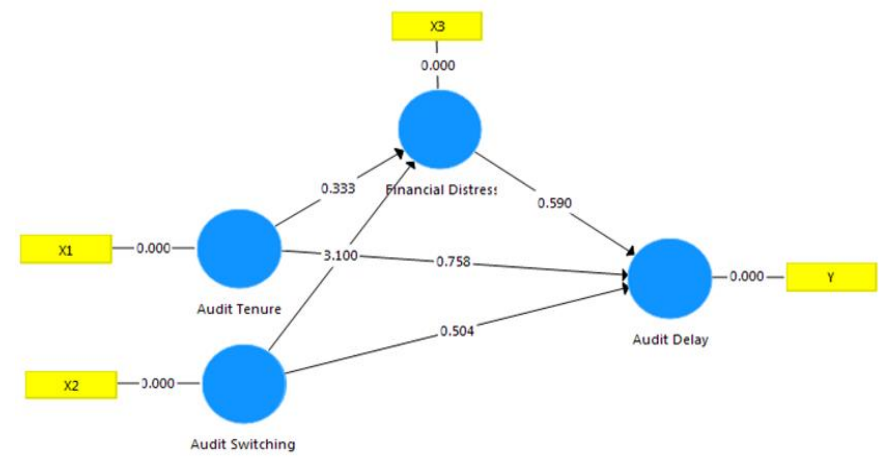

Fig. 3. Estimated model.

Based on the estimation results of the PLS model using the bootstrapping technique above, only auditor switching to financial distress has a p-value $<0.05$. The full significance test results of this direct effect can be seen in the following table 3: 
TABLE III. DIRECT EFFECT

\begin{tabular}{|c|l|l|l|l|c|}
\hline & $\begin{array}{c}\text { Original } \\
\text { Sample } \\
(\mathbf{O})\end{array}$ & $\begin{array}{c}\text { Sample } \\
\text { Mean } \\
(\mathbf{M})\end{array}$ & $\begin{array}{c}\text { Standard } \\
\text { Deviation } \\
\text { (STDEV) }\end{array}$ & $\begin{array}{c}\text { T } \\
\text { Statistic }\end{array}$ & $\begin{array}{c}\text { P } \\
\text { Values }\end{array}$ \\
\hline $\begin{array}{c}\text { Auditor } \\
\text { Switching } \\
\rightarrow \text { Audit } \\
\text { Delay }\end{array}$ & -0.093 & -0.085 & 0.184 & 0.504 & 0.614 \\
\hline $\begin{array}{c}\text { Auditor } \\
\text { Switching } \\
\rightarrow \\
\begin{array}{c}\text { Financial } \\
\text { Distress }\end{array}\end{array}$ & -0.330 & -0.329 & 0.106 & 3.100 & 0.002 \\
\hline $\begin{array}{c}\text { Audit } \\
\text { Tenure } \rightarrow \\
\text { Audit } \\
\text { Delay }\end{array}$ & 0.101 & 0.088 & 0.133 & 0.758 & 0.449 \\
\hline $\begin{array}{c}\text { Audit } \\
\text { Tenure } \rightarrow \\
\text { Financial } \\
\text { Distress }\end{array}$ & -0.048 & -0.054 & 0.144 & 0.333 & 0.739 \\
\hline $\begin{array}{c}\text { Financial } \\
\text { Distress } \rightarrow \\
\text { Audit } \\
\text { Delay }\end{array}$ & 0.079 & 0.072 & 0.134 & 0.590 & 0.556 \\
\hline
\end{tabular}

Source: SmartPLS result

It can be explained on the basis of the test results of the above hypothesis that, first, the p-value of the auditor switching effect on audit delay is 0.614 with a $\mathrm{T}$ statistic of 0.504 and the path coefficient is negative at 0.093 . It can be assumed that the frequency of auditor switching does not have a substantial effect on audit latency, since the p-value $>0.05$, $\mathrm{T}$ statistics < 1.68. It can be shown that only 9.3 percent of the variance in audit delay is determined by auditor switching, based on the value of the path coefficient that links the two variables.

Second, with a $\mathrm{T}$ statistic of 3.100, the p-value of the impact of the auditor switching on financial distress is 0.002 and the route coefficient is negative at 0.330 . Since the p-value $<0.05$, $\mathrm{T}$ statistic $>1.68$ and the negative path coefficient suggest that auditor switching has a negative and substantial impact on financial distress, this suggests that the more frequent the switching of the auditor, the better the financial conditions, and vice versa. It can be shown that 33 percent of the variance in financial distress is caused by auditor switching, based on the route coefficient value that links the two variables.

Thirdly, with a $\mathrm{T}$ statistic of 0.758 , the p-value of the impact of audit tenure on audit delay is 0.449 and the path coefficient is positive at 0.101 . It can be assumed that audit tenure does not have a major impact on audit delay because of the $\mathrm{p}$-value $>0.05, \mathrm{~T}$ statistic $<1.68$, and the positive path coefficient. It can be shown that only 10 percent of the variance in audit delay is affected by audit tenure, based on the path coefficient value that links the two variables.

Fourthly, with a $\mathrm{T}$ statistic of 0.333 , the p-value of the effects of audit tenure on financial distress is 0.739 and the direction coefficient is negative at 0.048 . It can be assumed that audit tenure does not have a major impact on financial distress because of the $\mathrm{p}$-value $>0.05, \mathrm{~T}$ statistic $<1.68$, and the negative path coefficient. It can be shown that just 4.8 percent of the variance in financial distress is affected by audit tenure, based on the path coefficient value that links the two variables.

Fifth, with a T statistic of 0.590 , the p-value of the impact of financial distress on audit delay is 0.556 and the path coefficient is positive at 0.079 . It can be assumed that financial distress does not have a major impact on audit delay because of the $\mathrm{p}$ values $>0.05, \mathrm{~T}$ statistics $<1.68$, and the positive path coefficient. It can be shown that only 7.9 percent of the variance in audit delay is affected by financial distress, based on the path coefficient value that links the two variables.

The financial distress variable is a mediating variable in this study that mediates the impact of audit tenure on audit delay and the switching of the auditor to audit delay. Table 4 below demonstrates the outcome of the test of the importance of the indirect impact of audit tenure and the auditor's turn to audit pause mediated by financial distress.

TABLE IV. INDIRECT EFFECT

\begin{tabular}{|c|c|c|c|c|c|}
\hline & $\begin{array}{c}\text { Original } \\
\text { Sample } \\
\text { (O) }\end{array}$ & $\begin{array}{c}\text { Sample } \\
\text { Mean } \\
(\mathrm{M})\end{array}$ & $\begin{array}{l}\text { Standard } \\
\text { Deviation } \\
\text { (STDEV) }\end{array}$ & $\begin{array}{c}\mathbf{T} \\
\text { Statistic }\end{array}$ & $\begin{array}{c}\mathbf{P} \\
\text { Values }\end{array}$ \\
\hline $\begin{array}{c}\text { Auditor } \\
\text { Switching } \\
\rightarrow \\
\text { Financial } \\
\text { Distress } \\
\rightarrow \text { Audit } \\
\text { Delay }\end{array}$ & -0.026 & -0.026 & 0.048 & 0.546 & 0.585 \\
\hline $\begin{array}{c}\text { Audit } \\
\text { Tenure } \rightarrow \\
\text { Financial } \\
\text { Distress } \\
\rightarrow \text { Audit } \\
\text { Delay }\end{array}$ & -0.004 & 0.006 & 0.023 & 0.163 & 0.871 \\
\hline
\end{tabular}

Source: SmartPLS results

The $\mathrm{p}$-value of the auditor's switching effect on audit delay with financial distress as an intermediate variable is 0.58 , based on the results of the indirect effect test in the table above. It can be inferred that the financial distress cannot mediate the auditor's transition to audit delay because the p-value obtained is greater than 0.05 . The impact of audit tenure on audit delay through financial distress also has a p-value of 0.8711 even with the effect of the auditor switching on audit delay through financial distress (higher than 0.05). This suggests that financial distress is unable to mediate audit tenure upon audit delay.

In addition, the value of $\mathrm{R}^{2}$ can be determined by the strength of the independent variables affecting the dependent variables. The intensity and weakness of the effect of the independent variable on the dependent variable can be shown by R-Square $\left(\mathrm{R}^{2}\right)$. The power and limitations of a research model can also be seen by R-Square $\left(R^{2}\right)$. The R-Square $\left(R^{2}\right)$ value of 0.67 is classified as a strong model, $R$-Square $\left(R^{2}\right)$ 0.33 is a moderate model, and R-Square $\left(R^{2}\right) 0.19$ is classified 
as a weak model, according to Chin [14]. In Table 5 below, the $\mathrm{R}^{2}$ of this study can be seen.

TABLE V. The VALUE OF R-SQuARE

\begin{tabular}{|c|l|}
\hline & \multicolumn{2}{|c|}{ R Square } \\
\hline Audit Delay & 0.029 \\
\hline Financial Distress & 0.111 \\
\hline
\end{tabular}

The $\mathrm{R}$ square value of the audit delay is 0.029 based on the findings of the review in the table above, which indicates that just 2.9 percent of the audit delay is affected by the tenure of the audit, the switching of the auditor, and financial distress. It can be concluded that it is very poor to state the model of the impact of audit tenure, auditor switching, and financial distress on audit delay. This value shows that only 11.1 percent of financial distress is affected by audit tenure and auditor switching. The $\mathrm{R}$ square of financial distress is 0.111 . It can be concluded that the model of the impact on financial distress of audit tenure and auditor switching is considered to be weak.

\section{Discussion}

This study found that the switching of the auditor has a negative effect on the audit delay but is not significant. This result confirms Pawitri and Yadnyana's analysis [15]. They reported that the company's trend in audit switching may have a negative effect. The newly hired auditor needs some time to audit the financial statement because they need more time to learn the features of the business and the client's implemented processes.

In this analysis, the impact of audit tenure on audit delays was found to be positive but not significant. This result is consistent with the outcome of Diastiningsih and Tenaya [16]. Diastiningsih and Tenaya [16] found that the audit tenure length is inversely proportional to the company's audit delay length. This occurs because the longer the audit tenure or the auditor-customer relationship, the greater the auditor's understanding of the company's profile, thus reducing the likelihood of audit delay [9].

This research found that the switching of the auditor has a negative and important impact on financial distress. When it suffers from financial distress, a corporation will terminate the auditor. In contrast to a well-performed business, a business suffering from financial difficulties appears to adjust the auditor. One of the key factors affecting the decision of a client to turn to an auditor is financial pressure [17].

When it comes to the financial results of a business, the audit switch is a negative signal to stakeholders. The business that suffers from financial difficulties has a greater chance of changing the auditor by finding a better independent auditor to boost their trust in stockholders and creditors. When an auditor switches or switches auditors from an entity, the more time the new auditor requires to learn the functionality of the client.

\section{CONCLUSION}

This study focuses on how audit tenure and auditor switching affect audit delay are audited and how financial distress mediates audit tenure and auditor switching to manufacturing companies listed on BEI 2016-2018 audit delay. The impact of audit tenure and audit switching on audit delays is not significant. This suggests that the amount of time auditors work with their customers does not affect the reporting time of financial statements. It is also found for auditor switching that the transition of the auditor does not impact the time of filing of the financial statements.

Audit tenure does not have a direct impact on financial distress, but financial distress is influenced by auditor switching. Indirectly, by financial distress, both audit tenure and auditor switching do not impact audit delay. This means that audit delay is not affected by the performance of the financial firm, while financial distress is affected by auditor switching. Audit tenure and auditor swapping have a limited value in affecting financial distress in this report. Although audit tenure, auditor switching, and financial distress have a slight effect on audit delay, audit delay is a strong predictor.

This study focuses on food and beverage companies and also the time period is from 2016 to 2018 . The further research can be suggested to investigate other sub-sectors of manufacturing company and also can make the period longer than the period used in this study.

\section{REFERENCES}

[1] K. Alkhatib and Q. Marji, "Audit Reports Timeliness: Empirical Evidence from Jordan," Procedia - Social and Behavioral Sciences, 62, 1342-1349, 2012.

[2] J. Al-Ajmi, "Audit and reporting delays: Evidence from an emerging market," Advances in Accounting, vol. 24, no. 2, pp. 217-228, 2008.

[3] C.A.P.N. Carslaw and S.E. Kaplan, "An Examination of Audit Delay: Further Evidence from New Zealand," Accounting and Business Research, vol. 22, no. 85, pp. 21-32, 1991 .

[4] M.A. Hossain and P.J. Taylor, "An Examination of Audit Delay: Evidence from Pakistan," Papers 64 for APIRA 98 in Osaka, pp. 1-16, 1998.

[5] B. Jaggi and T. Tsui, "Determinants of audit report lag: Further evidence from Hong Kong," Accounting and Business Research, vol. 30, no. 1, pp. 17-28, 1999.

[6] N. Khoufi and W. Khoufi, "An empirical examination of the determinants of audit report delay in France," Managerial Auditing Journal, vol. 33, no. 8-9, pp. 700-714, 2018.

[7] A.R. Almutairi, K.A. Dunn and T. Skantz, "Auditor tenure, auditor specialization, and information asymmetry," Managerial Auditing Journal, vol. 24, no. 7, pp. 600-623, 2009.

[8] A.A. Al-Thuneibat, R.T.I. Al Issa and R.A. Ata Baker, "Do audit tenure and firm size contribute to audit quality?: Empirical evidence from Jordan," Managerial Auditing Journal, vol. 26, no. 4, pp. 317-334, 2011.

[9] M. Dao and T. Pham, "Audit tenure, auditor specialization, and audit report lag," Managerial Auditing Journal, vol. 29, no. 6, pp. 490-512, 2014.

[10] C.W. Chow and S.J. Rice, "Qualified Audit Opinion and Auditor Switching," The Accounting Review, vol. 57, no. 2, 1982. 
[11] N.M. Haji-Abdullah and W.N. Wan-Hussin, "Audit Committee Attributes, Financial Distress and the Quality of Financial Reporting in Malaysia." SSRN Electronic Journal, November, pp. 1-40, 2011.

[12] P.Y.H. Praptika and N.K. Rasmini, "Pengaruh Audit Tenure, Pergantian Auditor dan Financial Distress pada Audit Delay pada Perusahaan Consumer Goods," E-Jurnal Akuntansi Universitas Udayana, vol. 15, no. 3, pp. 2052-2081, 2016.

[13] I. Ghozali and H. Latan, Partial Least Squares Konsep, Teknik, Dan Aplikasi Menggunakan Program SmartPLS 3.0 Edisi 2 (Untuk Penelitian Empiris), pp. 76 - 77, 2015.

[14] W.W. Chin, "Partial least squares is to LISREL as principal components analysis is to common factor analysis," Technology studies, vol. 2, no. 2, 315-319.
[15] N.M.P. Pawitri and K. Yadnyana, "Pengaruh Audit Delay, Opini Audit, Reputasi Auditor dan Pergantian Manajemen pada Voluntary Auditor Switching," E-Jurnal Akuntansi Universitas Udayana, vol. 10, no. 1, pp. 214-228, 2015.

[16] Diastiningsih, Ni Putu Julita, and Gede Agus Indra Tenaya, "Spesialisasi Auditor Sebagai Pemoderasi Pengaruh Audit Tenure dan Ukuran Kap pada Audit Report Lag,” E-Jurnal Akuntansi Universitas Udayana, 18, 2017.

[17] M.E. Haskin and D.D. Williams, "A Contingent Model of Intra-Big Eight Auditor Changes," Auditing: A Journal of Practice and Theory, vol. 9, no. 3, pp. 55-74, 1990. 